\title{
Pterospermumocarpon, a new malvalean fruit from the Sindhudurg Formation (Miocene) of Maharashtra, India, and its phytogeographical significance
}

\author{
Rashmi Srivastava*, R K Saxena and Gaurav Srivastava \\ Birbal Sahni Institute of Palaeobotany, 53 University Road, Lucknow 226 007, India. \\ *Corresponding author.e-mail: rashmi_bsip@yahoo.com
}

\begin{abstract}
Pterospermumocarpon (Type: P. kalviwadiensis), a new morphogenus of fossil fruits showing resemblance with fruits of extant Pterospermum Schreb. (Malvaceae s.l.), is described from the Sindhudurg Formation (Miocene) at the Kalviwadi Village, Sindhudurg District, Maharashtra, India. Diagnostic feature of the fossil taxon is the dehiscent pentalocular capsule with five distinct sutures and imprints of winged seedlike structures in the locules. Recent modifications in the systematics of the Malvales, their fossil record, and the distribution and migration of Pterospermum and other malvalean taxa in the context of the Indian subcontinent are discussed.
\end{abstract}

\section{Introduction}

The tropical Asian genus Pterospermum Schreb. is distributed from the Eastern Himalayas to South China and throughout Southeast Asia to the Moluccas (Ramesh Rao 1958; Mabberly 1997; Wilkie 2007). The name Pterospermum is of Greek origin, meaning 'winged seed'. Previously, the genus was included in the Sterculiaceae, however, it is now placed in the expanded Malvaceae (Bayer et al 1999; Bayer and Kubitzki 2003; Soltis et al 2005).

For the first time, Wilkinson (1871) reported deposits of obscure age and origin underlying the laterite in various quarry and well sections near Ratnagiri, Maharashtra. Saxena et al (1992) published the respective succession as developed in the Ratnagiri and Sindhudurg districts of Maharashtra, which was later described as Sindhudurg Formation. This formation rests unconformably on Precambrian rocks or Deccan Traps and is overlain by laterites. The lithostratigraphic unit 'Sindhudurg Formation' was proposed by Saxena (1995) for a sequence of clays with carbonaceous and lignitic beds developed in a large area along the Konkan Coast of Maharashtra, India. Plant remains are known from the lignite and carbonaceous clays of this formation (figure 1). The stratigraphic section studied here consists of grey clay $(1.0 \mathrm{~m})$ at the base followed by lignite $(1.0 \mathrm{~m})$, an ironstone band $(0.1 \mathrm{~m})$, grey clay $(0.5 \mathrm{~m})$ and laterite $(>4.0 \mathrm{~m})$ (figure 1b). The lignite contains well-preserved carbonized woods, fruits and seeds.

Plant megafossils recorded from the Sindhudurg Formation of the Konkan Coast, Maharashtra are given in table 1 . In addition, a diversity of fungal remains (Saxena and Misra 1990; Saxena 2000; Tewari and Agarwal 2001; Tewari 2002; Rao 2003, 2004), wood fragments, leaves, cuticles with stomata and terrestrial organic matter has been described along with palynofossils (Phadtare and Kulkarni 1980a, 1980b, 1984a, 1984b; Kulkarni and

Keywords. Pterospermumocarpon gen. nov.; Pterospermum; Malvaceae; phytogeography; Miocene; India; fossil fruit; Sindhudurg Formation; Maharashtra. 


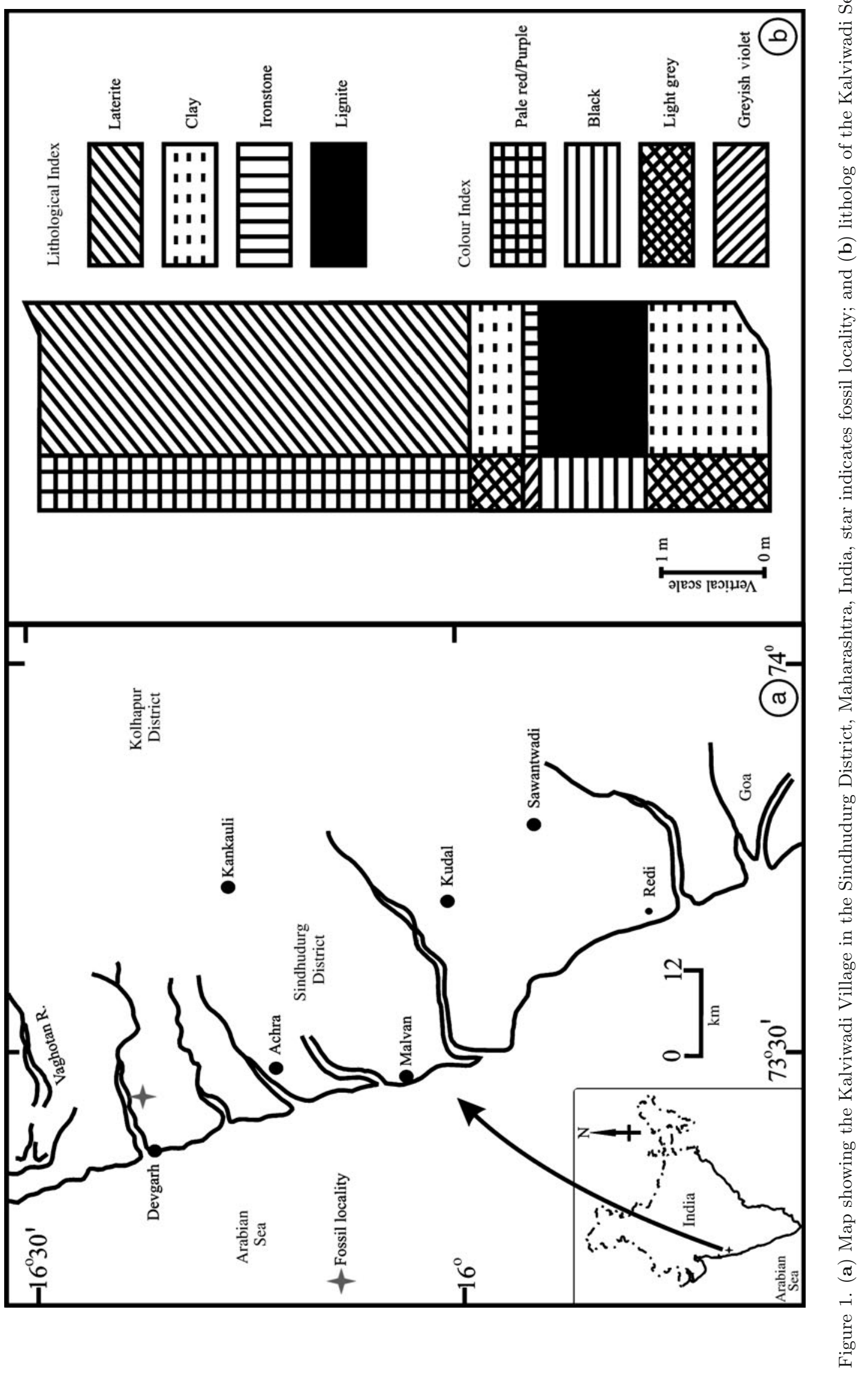


Table 1. Plant megafossils recorded from Konkan Coast of Maharashtra, India.

\begin{tabular}{lll}
\hline Family & Fossil species/plant part & Reference \\
\hline Alangiaceae & Alangium, cuticle & Dalvi and Kulkarni (1982) \\
Anacardiaceae & Anacardioxylon ratnagiriense, wood & Phadtare and Kulkarni (1984c) \\
& Dracontomelumoxylon mangiferumoides, wood & Srivastava and Saxena (1999) \\
& Bouea rediensis, wood & Dalvi and Kulkarni (1982) \\
Nothopegia, cuticle & Shinde and Kulkarni (1989) \\
Arecaceae & Eugeissonocarpon indicum, fruit & Kulkarni and Phadtare (1980) \\
Burseraceae & Nypa, cuticle & Agarwal and Ambwani (2000) \\
Clusiaceae & Canariocarpon ratnagiriensis, fruit & Dalvi and Kulkarni (1982) \\
Combretaceae & Garcinia, cuticle & Agarwal (2005) \\
Dipterocarpaceae & Terminalia praechebula, seed & Srivastava and Saxena (1999) \\
Ebenaceae & Shoreoxylon vayganiensis, wood & Dalvi and Kulkarni (1982) \\
Fabaceae & Diospyros, cuticle & Agarwal (2003) \\
Nyssaceae & Entada palaeoscandens, seed & Shinde and Kulkarni (1989) \\
Rubiaceae & Nyssa brandoniana, fruit & Agarwal and Ambwani (2002) \\
Incertae sedis & Amberiwadiacarpon devgarhensis, fruit & Agarwal et al (2002) \\
\end{tabular}

Phadtare 1983; Kulkarni et al 1985; Saxena and Misra 1990; Saxena et al 1992; Saxena 2000; Tewari and Agarwal 2001; Rao 2004). Malvalean pollen, known as Malvacearumpollis, has been recorded by Saxena and Misra (1990) and Rao (2004).

\section{Methodology}

A number of carbonized fruits, described here as Pterospermumocarpon kalviwadiensis gen. et sp. nov., were collected from a lignite bed of the Sindhudurg Formation exposed at the Kalviwadi Village (lat. $16^{\circ} 24^{\prime} 30^{\prime \prime} \mathrm{N}$ : long. $73^{\circ} 26^{\prime} 10^{\prime \prime} \mathrm{E}$ ). This exposure is located about $0.6 \mathrm{~km}$ east of the Mondtar Bus-stop in the Devgarh Subdivision, Sindhudurg District, Maharashtra, India (figure 1a). For anatomical details, the fruits were studied under Scanning Electron Microscopic (SEM). For SEM study, the specimens were mounted on aluminum stubs with the help of double-sided adhesive tape and then coated with gold-palladium alloy on a Polaron Sputter Coater. The coated samples were studied under SEM LEO-430 and photographs were taken in desired magnifications. The type material is deposited in the collections of the Birbal Sahni Institute of Palaeobotany, Lucknow, India.

\section{Systematic description}

Order: Malvales

Family: Malvaceae s.l.
Subfamily: Dombeyoideae

Genus: Pterospermumocarpon R Srivast., R K Saxena and Gaurav Srivast., gen. nov.

Type species: Pterospermumocarpon kalviwadiensis R Srivast., R K Saxena and Gaurav Srivast., sp. nov.

Generic diagnosis: Fruit capsule, loculicidal, dehiscent, symmetrical, elliptic to lanceolate in shape, apex acute, base obtuse, pentalocular, five distinct sutures seen on the surface separating each locule, capsule wall thick, seed wings represented by imprint on the inner surface.

Etymology: The generic name indicates the resemblance of the fossil fruit with the fruits of modern Pterospermum Schreb.

Pterospermumocarpon kalviwadiensis $\mathrm{R}$ Srivast., R K Saxena and Gaurav Srivast., sp. nov.

Description: Fruit capsule, loculicidal, dehiscent, symmetrical, elliptic to lanceolate in shape, length $3.0 \mathrm{~cm}$, diameter $1.5 \mathrm{~cm}$, apex acute, base obtuse, stalk broken; pentalocular, five distinct sutures present (figure 2a); pericarp 2.7-mm thick, epicarp $0.6 \mathrm{~mm}$, mesocarp $2.0 \mathrm{~mm}$, endocarp not distinct. Under higher magnification, venation-like pattern representing imprints of seed wings, may be observed on the inner surface of the locules in few capsules (figure 2d, e). Seeds not preserved.

Epicarp cells predominantly rectangular and moderately thick-walled with striated ornamentation (figure $3 \mathrm{~b}$ ); mesocarp cells oval to circular 

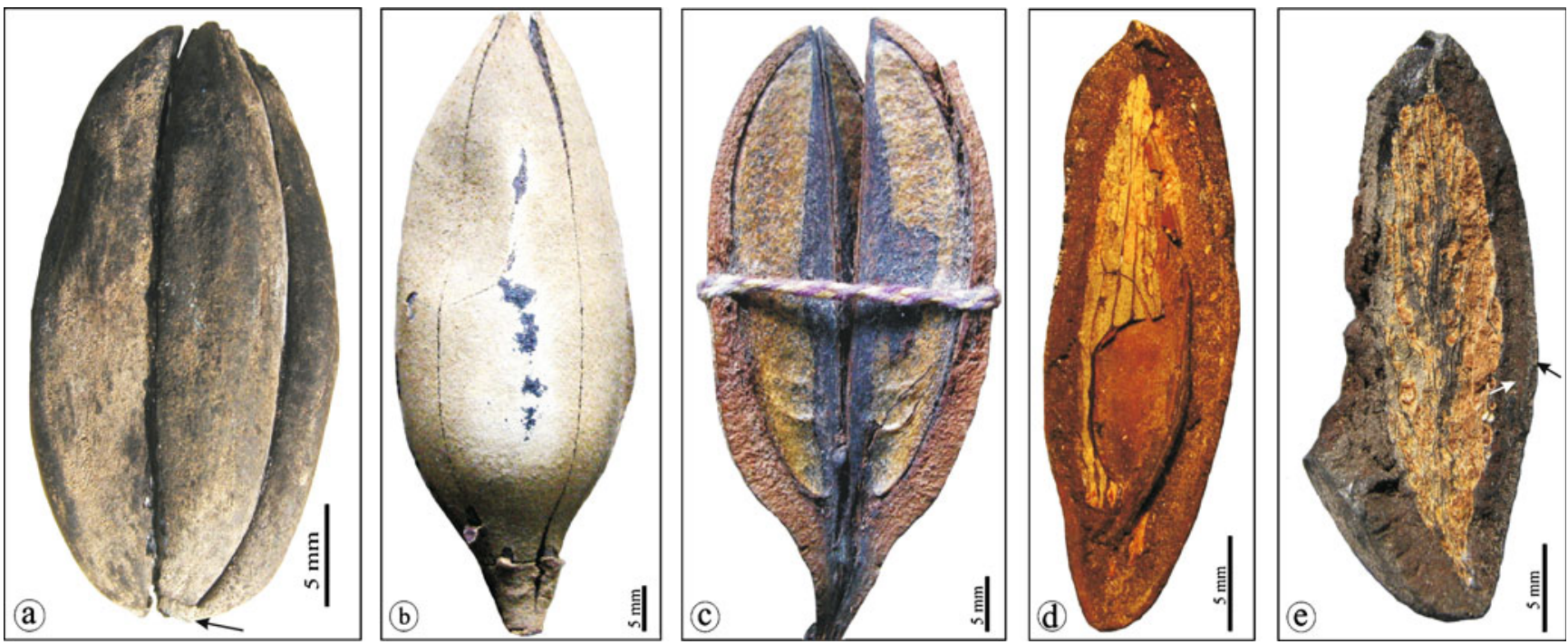

Figure 2. (a) Carbonized fruit of Pterospermumocarpon kalviwadiensis, Holotype specimen no. BSIP 39896; (b, c) Fruit of extant Pterospermum subrifolium CNH No. 17177 (d, e) Another specimen of a dehisced carbonized fruit of Pterospermumocarpon kalviwadiensis, specimen no. BSIP 39897.

with few polygonal ones, cell wall thicker than that of epicarp cells, frequently perforated, spongypapillate bodies protrude into the cell lumen from perforations in the cell wall (figure 3c, d); endocarp not very distinct, cells of the inner layer very thick-walled, hexagonal stone cells with very small lumen (figure 3f); frequently pitted vascular strands present (figure $3 \mathrm{~g}, \mathrm{~h}$ ).

Holotype: Specimen no. BSIP 39896.

\section{Additional Specimen: BSIP 39897.}

Type locality: Kalviwadi Village, Sindhudurg District, Maharashtra, India.

Type horizon: Sindhudurg Formation.

Age: Miocene.

\subsection{Affinities and comparison}

Diagnostic feature of the present fossil taxon is the dehiscent pentalocular capsule with five distinct sutures and imprints of wing-like structures in the locules, indicating its affinity with the genus Pterospermum Schreb. of the Malvaceae. In external morphology and size, the carbonized fruits also show some resemblance with the fruits of Alseodaphne andersonii (King ex Hook. f) Koestrum. of the Lauraceae and Canarium strictum Roxb. of the Burseraceae. However, the fruits of Alseodaphne are indehiscent with a single seed and the Canarium fruits are also indehiscent but trilocular with small seeds without wings.
In order to find the nearest modern equivalent of the present fossil taxon, a large number of Pterospermum fruits and other malvalean fruits with a dehiscent capsule and membranaceous winged seeds were studied at the Central National Herbarium, Howrah, Forest Research Institute, Dehradun, and Birbal Sahni Institute of Palaeobotany, Lucknow, India. Amongst them, Pterospermum suberifolium Lam. (Hebarium Sheet no. 17177; figure 2b, c), $P$. acerifolium Wild, and $P$. lancaefolium Roxb. show closest resemblance with the fruit under consideration. However, in modern Pterospermum species, mature fruits are woody capsules and much bigger in size than the fossil fruits under consideration. Therefore, a new morphogenus Pterospermumocarpon is proposed herewith.

Two other genera of fossil fruits, namely, Canariocarpon ratnagiriensis (Agarwal and Ambwani 2000) and Amberiwadiacarpon devgarhensis (Agarwal and Ambwani 2002) have earlier been described from the same locality. Canariocarpon ratnagiriensis (Burseraceae) is a trilocular, faintly triangled, indehiscent fruit with many seeds in each locule quite different from the present fruit. Amberiwadiacarpon devgarhensis differs markedly in having prominent ridges and furrows on the outer surface and being larger in size $(7.5 \times 5.5 \mathrm{~cm})$. The latter fruit is provisionally placed in the Rubiaceae without reference to any of its extant taxa. Since these two, as well as other fruits described so far from Late Cretaceous to Tertiary sediments, are quite different from the fruit under consideration, it is assigned to Pterospermumocarpon kalviwadiensis R Srivast., R K Saxena and Gaurav Srivast., gen. et sp. nov. 


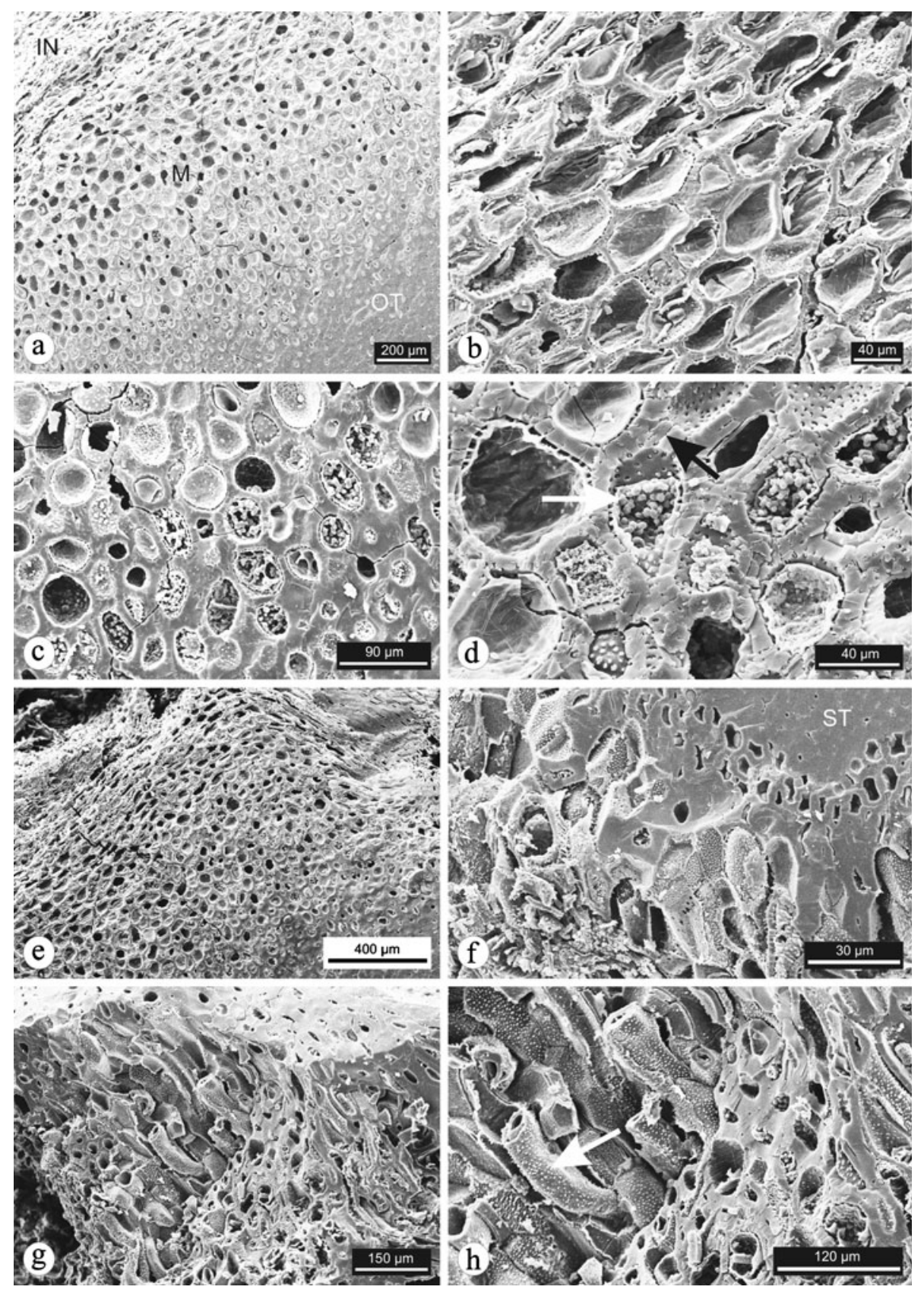

Figure 3. (a) Details showing epicarp - outer (OT), mesocarp - middle (M) and endocarp - inner (IN) layers of fruit wall; (b) outer layer having rectangular and moderately thick walled with striated ornamentation; (c) the cells of middle layer oval to circular in shape with few polygonal ones; (d) details of (c) showing frequently perforated cell walls (marked with black arrow) and spongy-papillate bodies protruding into the cell lumen (marked with white arrow); (e) inner and middle layer cells at low magnification; (f) thick-walled stone cells (ST) of inner layer with vascular strands; (g, h) inner layer showing frequently pitted vascular strands (marked with arrow), inter-vascular pits small, alternate and bordered (f-h).

Etymology: The specific epithet refers to the Kalviwadi village, where the fossils were collected.

The genus Pterospermum Schreb. consists of approximately 25 to 30 species (Mabberly 1997; Wilkie 2007). It is a tropical Asiatic genus widely distributed in the evergreen to semievergreen forests of India, Indonesia, Malaysia, the Philippines and southern China. It is mostly found growing naturally along forested stream banks.
The best growing conditions are met in a moist climate with access to full sunlight. In India, about 10 species are distributed in Western Ghats, the Andaman Islands and Kutch. The nearest modern counterparts of the fossil fruits, viz., P. lancaefolium Roxb., a medium-sized tree of eastern India (Khasi Hills, Manipur) and Bangladesh, and $P$. subrifolium Lam., a small to medium-sized tree found in Deccan on the east coast inland hills of 
Orissa, and Cuddapah, and also in the drier regions of Sri Lanka (Ramesh Rao 1958).

\section{Discussion}

The genus Pterospermum, earlier placed in the Sterculiaceae, is now merged into the Dombeyoideae of the Malvaceae s.l. The circumscription of Malvaceae is controversial. In the Cronquist system, Sterculiaceae, Malvaceae, Bombacaceae and Tiliaceae constitute the 'Core Malvales' because of the close relationship among these families. However, systematic position of the Malvales Juss. has recently undergone significant modification on the basis of cladistic or phylogenetic analysis (Judd and Manchester 1997) and molecular studies (Alverson et al 1999; Worberg et al 2009). They excluded Elaeocarpaceae from the Malvales and placed the rest of the families in a single family Malvaceae Juss. The families clustered under Malvaceae s.l. were treated as nine subfamilies (Bayer et al 1999; Bayer and Kubitzki 2003; Soltis et al 2005). However, Baum et al (1998); Cheek (2006) and Heywood et al (2007) favour a restricted concept of 10 families, viz., Bombacaceae Kunth, Brownlowiaceae Cheek, Byttneriaceae R Br., Durionaceae Cheek, Helicteraceae J Agardh, Malvaceae Juss. s.s., Pentapetaceae Berch and J. Presl, Sparmanniaceae J Agardh, Sterculiaceae (DC) Bartl. and Tiliaceae Juss. Recently, Kvaček and Wilde (2010) opted for Malvaceae s.l. while describing fossil malvalean leaves and seeds from Europe because this appears more convenient for palaeobotanical studies. We are following the same concept as it is widely practised by a majority of modern taxonomists.

From India, the Malvaceae s.l. are welldocumented by megafossils (Srivastava 1991; Srivastava and Guleria 2006) as well as by pollen records (Saxena 1991; Saxena and Trivedi 2006). These are listed in table 2. Fossil woods (Pterospermoxylon kutchensis Awasthi et al 1980, P. bengalensis Roy and Mukhopadhyay 2005) and leaves (Pterospermum palaeoheyneanum Antal and Awasthi 1994, P. siwalicum Antal and Prasad 1996), showing affinities with the genus Pterospermum, are recorded from the Neogene sediments of India.

\subsection{Phytogeographical aspect}

During the Early Cretaceous, India separated from Gondwanaland and moved northwards until it collided with the Asian landmass during the Early Tertiary. Following collision of the two plates, land connections were established between the Indian subcontinent and Southeast Asia during the Neogene (Smith et al 1994). As a result, vis-à-vis migration of a number of taxa took place, in both plants and animals, ultimately resulting in the evolution of modern floras and ecosystems (Rao 1974; Awasthi and Srivastava 2005; Srivastava and Mehrotra 2010). During the Neogene, the Dipterocarpaceae, which are considered to be of Malaysian origin (Lakhanpal 1974), entered India from Southeast Asia via Myanmar, along with a number of fabaceous, ebenaceous, sapotaceous and malvalean genera. Bande and Prakash (1986) traced the migration of various taxa between the two landmasses.

The Malvaceae are an interesting example indicating vis-à-vis migration of a number of taxa. Of these, the genus Pterospermum is recorded from the Palaeogene of Borneo as Phyllites (Pterospermum) gracilis Geyler (1875). In India, Pterospermum makes its first appearance in the Neogene (Awasthi et al 1980; Antal and Awasthi 1994; Antal and Prasad 1996; Roy and Mukhopadhyay 2005). Another malvalean genus, Grewia, which is well-documented from the Deccan Intertrappean bed (Maastrichtian-Danian) of India (table 2), has been recorded from the Neogene sediments of South Vietnam as Grewinium fontansii Serra (1981) and from the Miocene sediments of Chindwin, Myanmar as Grewioxylon burmense and $G$. macroporosum (Gottwald 1994). Likewise, Sterculia is recorded from the Maastrichtian-Palaeogene sediments of India (table 2) and from the Neogene sediments of Myanmar as Sterculinium foetidense (Prakash 1973; Guleria 1983). A leaf of the genus Bombax (Bombacites orientalis) has also been recorded from the Late Palaeocene sediments of Garo Hills, Meghalaya, India (table 2), whereas its wood (Bombacoxylon) has been recorded from the Neogene sediments of Myanmar (Gottwald 1969), further providing evidence for vis-à-vis migration of malvalean taxa from both regions. The occurrence of Bombacoxylon owenii (=Dombeyoxylon oweni Kräusel) in the Eocene and Oligocene sediments of Libya and Algeria and the Late Cretaceous or Eocene sediments of Ethiopia (Beauchamp and Lemoigne 1973) and Dombeyoxylon monodii (Boureau 1949) in the Tertiary sediments of Algeria and West Africa further supports a palaeotropical origin of the Dombeyoideae and a Gondwanan origin of the Malvaceae.

The present day distribution of Malvaceae suggests that, except Tilioideae, it originated in Gondwanaland (Southern Hemisphere). However, the modern distribution is not significant unless the fossil record is taken into consideration. The fossil record of the family extends back into the Late Cretaceous. The subfamily Dombeyoideae is palaeotropical, with centres of diversity in 


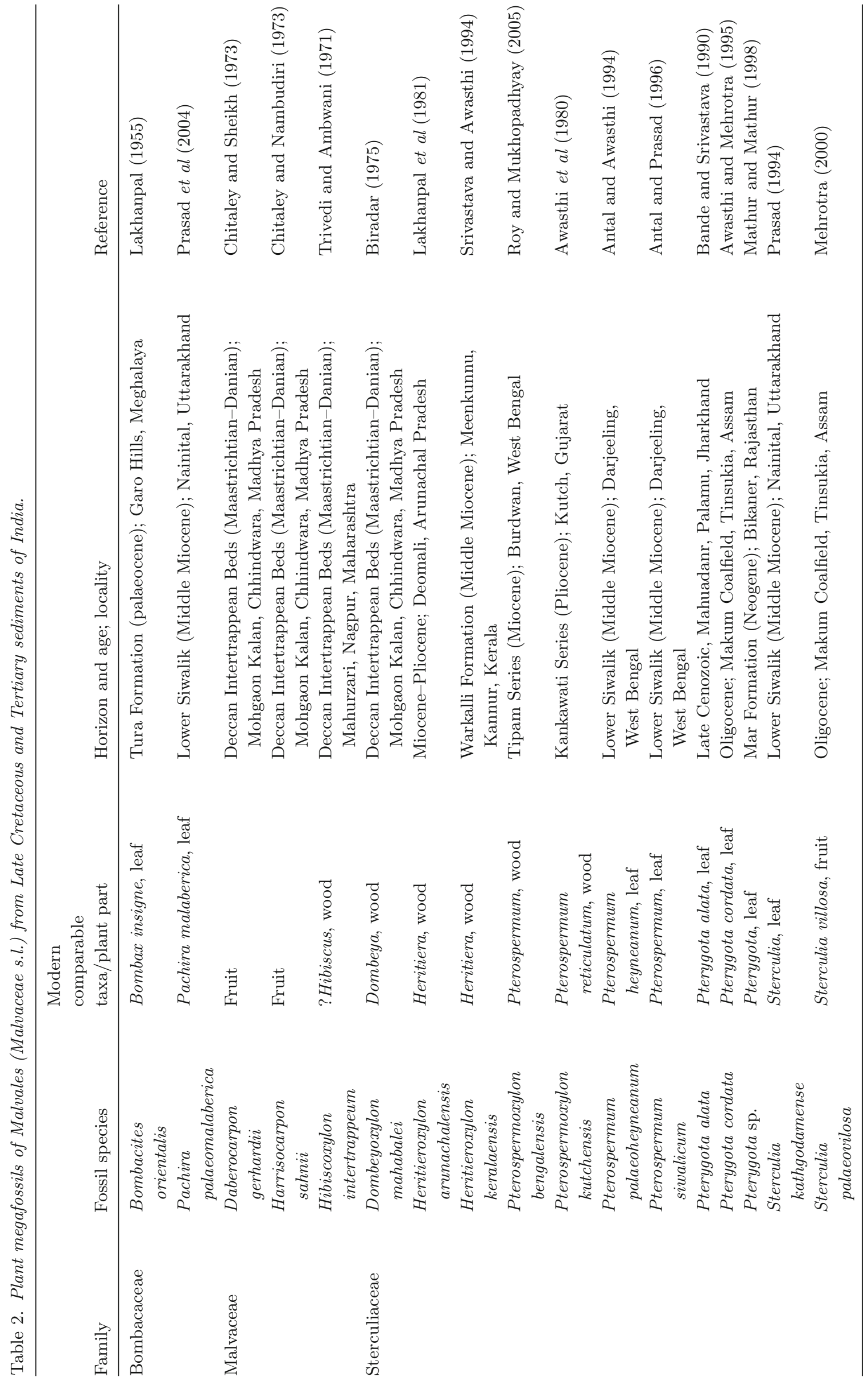




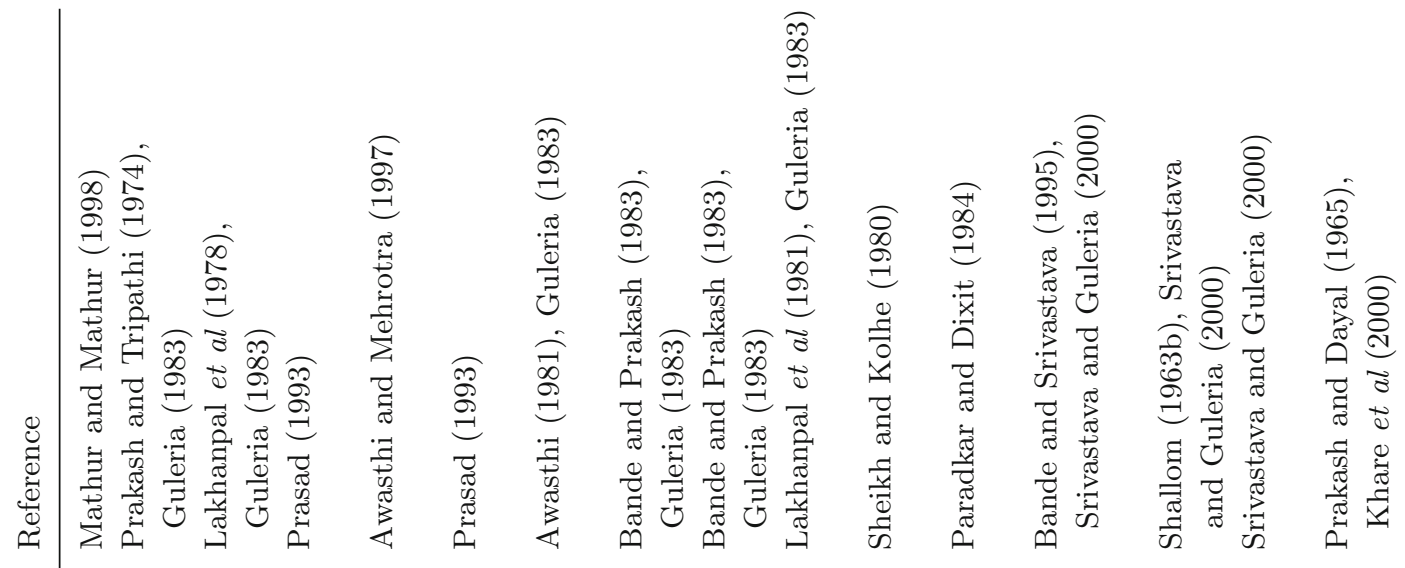

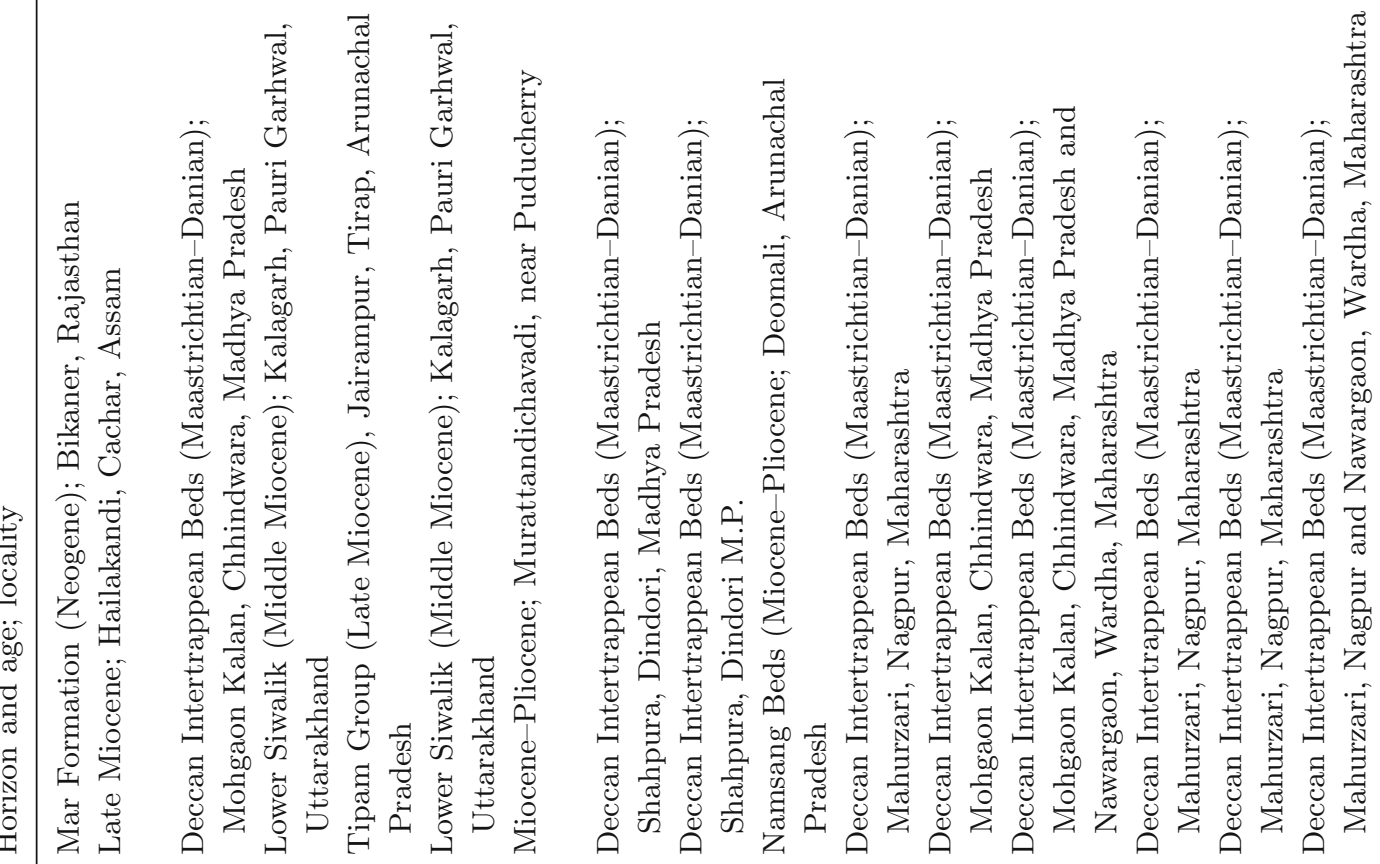

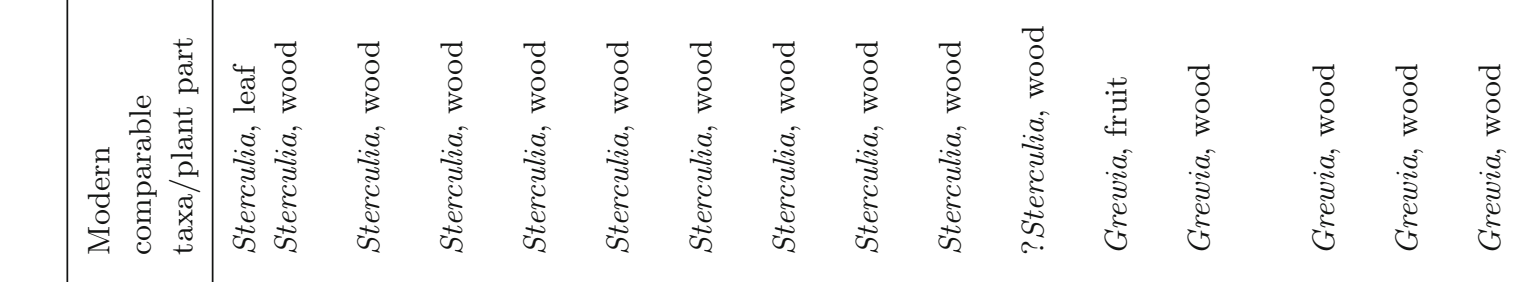

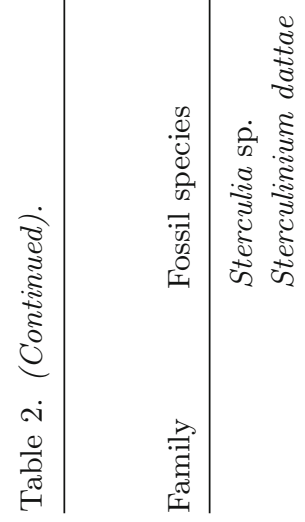

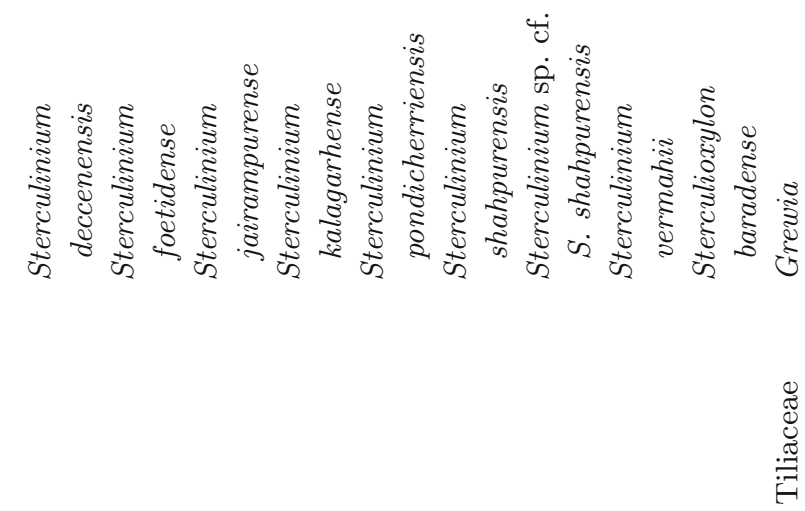

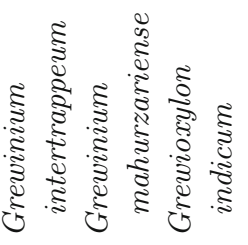


Madagascar and Southeast Asia and seems to be of East Gondwanan origin. However, fossils have also been reported from the Eocene sediments of North America (Chattawaya paliformis Manchester 1980) and Europe (Dombeyoxylon sturanii Charrier 1967, Saportaspermum kovacsiae Kvaček and Wilde 2010) comparable with the seeds of Pterospermum).

\section{Conclusion}

The occurrence of Pterospermumocarpon and the fossil woods and leaves showing affinity to Pterospermum in the Neogene sediments along with a number of other malvalean taxa in the Maastrichtian-Danian of India (table 2) clearly indicates vis-à-vis migration of Malvaceae from India to Southeast Asia. On the basis of the fossil record, the Malvaceae probably have a palaeotropical origin in the Southern Hemisphere. After land connection between the Indian subcontinent and Southeast Asia was established during the Neogene, new routes were opened for vis-à-vis migration of a number of taxa which ultimately resulted in the evolution of the modern flora of both regions.

\section{Acknowledgements}

The authors are grateful to the Director, Birbal Sahni Institute of Palaeobotany, Lucknow (India) for permission to publish the paper. Suggestions made by Dr. habil. Volker Wilde of the Senkenberg Forschungsinstitut und Naturmuseum, Frankfurt, Germany and by anonymous reviewer are gratefully acknowledged. We are also thankful to the authorities of the Forest Research Institute, Dehradun, and the Central National Herbarium, Botanical Survey of India, for permission to consult their Herbaria.

\section{References}

Agarwal A 2003 A carbonised fossil seed, viz., Entada palaeoscandens (Awasthi and Prasad) Antal and Awasthi, from lignite deposits of Kalviwadi, Sindhudurg District, Maharashtra, India; Phytomorphology 53(2) 133-139.

Agarwal A 2005 A carbonised fossil seed Terminalia praechebula sp. nov. from Kalviwadi, Sindhudurg District, Maharashtra, India; Phytomorphology 55(1-2) 85-92.

Agarwal A and Ambwani K 2000 Canariocarpon ratnagiriensis gen. et sp. nov. from Sindhudurg District, Maharashtra, India; Palaeobotanist 49(1) 93-100.

Agarwal A and Ambwani K 2002 Amberiwadiacarpon devgarhensis gen. et sp. nov. from Amberiwadi, Sindhudurg District, Maharashtra, India; Palaeobotanist 51 107-111.

Agarwal A, Tewari R and Ambwani K 2002 Dispersed angiospermous cuticles from Sindhudurg Formation,
Miocene, Ratnagiri District, Maharashtra, India; Phytomorphology 52(1) 29-40.

Alverson W S, Whitlock B A, Nyffeler R, Bayer C and Baum D A 1999 Phylogeny of core Malvales: Evidence from $n d h F$ sequence data; Am. J. Bot. 86 1474-1486.

Antal J S and Awasthi N 1994 Fossil flora from the Himalayan foot-hills of Darjeeling District, West Bengal and its palaeoecological and phytogeographical significance; Palaeobotanist 42(1) 14-60.

Antal J S and Prasad M 1996 Some more leaf impressions from the Himalayan foot-hills of Darjeeling District, West Bengal, India; Palaeobotanist 43(2) 1-9.

Awasthi N 1981 Fossil woods belonging to Sterculiaceae and Lythraceae from the Cuddalore Series near Pondicherry; Palaeobotanist 27(2) 182-189.

Awasthi N, Guleria J S and Lakhanpal R N 1980 Fossil dicotyledonous woods from the Pliocene beds of Mothala, district Kutch, western India; Palaeobotanist 26(3) 199-205.

Awasthi N and Mehrotra R C 1995 Oligocene flora from Makum Coalfield, Assam, India; Palaeobotanist 44 $157-188$.

Awasthi N and Mehrotra R C 1997 Some fossil dicotyledonous woods from the Neogene of Arunachal Pradesh, India; Palaeontographica B 245 109-121.

Awasthi N and Srivastava R 2005 Neogene flora of Kerala coast and its palaeoecological and phytogeographical implications; In: Gleanings in botanical research - current scenario, Ramanujam Commemoration Volume (ed.) Bir Bahadur (Nagpur: India Dattsons), pp. 265-277.

Bande M B and Prakash U 1983 Fossil dicotyledonous woods from the Deccan Intertrappean beds near Shahpura, Mandla District, Madhya Pradesh; Palaeobotanist 31(1) $13-29$.

Bande M B and Prakash U 1986 The Tertiary flora of Southeast Asia with remarks on its palaeoenvironment and phytogeography of the Indo-Malayan region; Rev. Palaeobot. Palynol. 49 203-233.

Bande M B and Srivastava G P 1990 Late Cenozoic plant impressions from Mahuadanr Valley, Palamu District, Bihar; Palaeobotanist 37(3) 331-366.

Bande M B and Srivastava R 1995 Grewia-type of fossil woods from the Deccan Interterappean beds of India; Geophytology 24(2) 131-136.

Baum D A, Alverson W S and Nyffeler R 1998 A durian by any other name: Taxonomy and nomenclature of core Malvales; Harvard Pap. Bot. 3(2) 315-330.

Bayer C, Fay M F, De Bruijn A Y, Savolainen V, Morton C M, Kubitzki K and Chase M W 1999 Support for an expanded family concept of Malvaceae within a recircumscribed order Malvales: A combined analysis of plastid atp $B$ and $r b c L$ DNA sequence; Bot. J. Linn. Soc. 129 267-303.

Bayer C and Kubitzki K 2003 Malvaceae; In: The families and genera of vascular plants V. Flowering plants Dicotyledons, Malvales, Capparales and non-betalain Caryophyllales (eds) Kubitzki K and Bayer C (Berlin: Springer-Verlag), pp. 225-311.

Beauchamp J and Lemoigne Y 1973 Description d'une paleoflore du Cretace terminal-Eocene dans le massif du Chercher (province d'Harar, Ethiopie); Documents des Laboratoires de Geologie de la Faculte des Sciences de Lyon 56 167-180.

Biradar N V 1975 On the occurrence of Dombeyoxylon Schenk in the Deccan Interterappean beds of Mohgaon Kalan, District Chhindwara; Geophytology 3(1) 3641.

Boureau E 1949 Etude palaeoxylologique du Sahara (V); Sur une forme nouvelle de Dombeyoxylon monodii n. sp., 
sterculiacee fossile des environs de Tindouf et de l' Azaouad; Bull. Museum National d' Histoire Naturelle 21(5) 639-646.

Charrier G 1967 Legno di Sterculacea dell'eocene medio continentale del Lauzanier (autoctono sedimentario dell' Argentera, Basses Alps, Francia), Bollettino.

Cheek M 2006 The validation of two new family names in Malvales: Durionaceae and Brownlowiaceae; Kew Bull. 61443.

Chitaley S D and Nambudiri E M V 1973 Harrisocarpon sahnii gen. et sp. nov. from the Deccan Interterappean beds of Mohgaon-Kalan, District Chhindwara; Geophytology 3(1) 36-41.

Chitaley S D and Sheikh M T 1973 A ten locular fruit from the Deccan Interterappean Series of India; Palaeobotanist 20(3) 297-299.

Dalvi N S and Kulkarni A R 1982 Leaf cuticles from lignitic beds of Ratnagiri, Maharashtra; Geophytology 12(2) 223-232.

Geyler T T 1875 Über fossile Pflanzen von Borneo; Palaeontographica Suppl. 3 1(1) 60-84.

Gottwald H 1969 Zwei Kieselholzer aus dem Oligozan von Tunis, Bombacoxylon oweni und Pseudolachnostyloxylon weylandii; Palaeontographica B 125 112-116.

Gottwald H 1994 Tertiäre Hölzer aus dem Chindwin-Bassin im nordwestlichen Myanmar (Birma); Documentae naturae 86 1-90.

Guleria J S 1983 Some fossil woods from Tertiary of Kachchh, western India; Palaeobotanist 31(3) 109-128.

Heywood V H, Brummitt R K, Culham A and Seberg O 2007 Flowering plant families of the world; Royal Botanic Gardens, Kew.

Judd W S and Manchester S R 1997 Circumscription of Malvaceae (Malvales) as determined by a preliminary cladistic analysis of morphological, anatomical, palynological and chemical characters; Brittonia 49 384-405.

Khare E G, Prasad M and Awasthi N 2000 Contributions to the Deccan Intertrappean flora of Nawargaon, Wardha District, Maharashtra, India; Palaeobotanist 49(3) 443-460.

Kulkarni A R and Phadtare N R 1980 Leaf epidermis of Nypa from lignitic beds of Ratnagiri District, Maharashtra; Geophytology 10(2) 125-128.

Kulkarni A R and Phadtare N R 1983 Pollen of Nypa from lignite beds of Ratnagiri District, Maharashtra; Phytomorphology 31(1-2) 48-51.

Kulkarni A R, Phadtare N R and Dalvi N 1985 Monocotyledonous pollen grains from Ratnagiri lignite; In: Recent advances in pollen research (ed.) Verghese T M (India: Allied Publishers Private Limited), pp. 295-313.

Kvaček Z and Wilde V 2010 Foliage and seeds of malvalean plants from the Eocene of Europe; Bull. Geosci. 85(1) 163-182.

Lakhanpal R N 1955 Recognizable species of Tertiary plants from Damalgiri in Garo Hills, Assam; Palaeobotanist 3 27-31.

Lakhanpal R N 1974 Geological history of the Dipterocarpaceae; In: Symposium on Origin and Phytogeography of Angiosperms, Lucknow, pp. 30-39.

Lakhanpal R N, Prakash U and Awasthi N 1981 Some more dicotyledonous woods from the Tertiary of Deomali, Arunachal Pradesh; Palaeobotanist 27(3) 232-252.

Lakhanpal R N, Prakash U and Bande M B 1978 Fossil dicotyledonous woods from the Deccan Intertrappean Beds of Mandla District, Madhya Pradesh; Palaeobotanist 25 190-204.

Mabberly D J 1997 The plant book, a portable dictionary of the vascular plants; 2nd edn (Cambridge: Cambridge University Press).
Manchester S R 1980 Chattawaya (Sterculiaceae): A new genus of wood from the Eocene of Oregon and its implications for xylem evolution of the extant genus Pterospermum; Am. J. Bot. 67(1) 59-67.

Mathur U B and Mathur A K 1998 A Neogene flora from Bikaner, Rajasthan; Geosci. J. 19(2) 129-144.

Mehrotra R C 2000 Two new fossil fruits from Oligocene sediments of Makum Coalfield, Assam, India; Curr. Sci. 79(10) 1482-1483.

Paradkar S A and Dixit V P 1984 Grewia mohgaoensis - a new petrified dicotyledonous fruit from the Deccan Intertrappean Beds of Mohgaon Kalan, Madhya Pradesh, India; In: Proc. 5th Indian Geophytological Conference, Lucknow, 1983 (eds) Tiwari R S et al (Lucknow: Special Publication of Palaeobotanical Society), pp. 155-162.

Phadtare N R and Kulkarni A R 1980a Palynological investigation of Ratnagiri lignite, Maharashtra; Geophytology 10(2) 158-170.

Phadtare N R and Kulkarni A R 1980b Laevigatosporites ovalis Wilson and Webster with its sporangium from lignite beds of Ratnagiri District; Curr. Sci. 49603.

Phadtare N R and Kulkarni A R 1984a Affinity of the genus Quilonipollenites with the Malaysian palm Eugeissona Griffith.; Pollen Spores 26 217-226.

Phadtare N R and Kulkarni A R 1984b Palynological assemblage of lignite exposure of Ratnagiri District; In: Proc. 10th Indian Colloqium Micropalaeontology and Stratigraphy, Pune, 1982 (eds) Badve $\mathrm{R} \mathrm{M}$ et al (Pune: Maharashtra Association for the Cultivation of Science), pp. 515-531.

Phadtare N R and Kulkarni A R 1984c Woods of Anacardiaceae from lignitic beds of Ratnagiri District, Maharashtra, India; In: Proc. 5th Indian Geophytological Conference, Lucknow, 1983 (eds) Tiwari R S et al (Lucknow: Special Publication of Palaeobotanical Society), pp. $232-241$.

Prakash U 1973 Fossil woods from the Tertiary of Burma; Palaeobotanist 20(1) 48-70.

Prakash U and Dayal R 1965 Fossil woods of Grewia from the Deccan Intertrappean Series, India; Palaeobotanist 13(1) $17-24$.

Prakash U and Tripathi P P 1974 Fossil woods from Tertiary of Assam; Palaeobotanist 21(3) 305-316.

Prasad M 1993 Siwalik (Middle Miocene) woods from the Kalagarh area in the Himalayan foot hills and their bearing on palaeoclimate and phytogeography; Rev. Palaeobot. Palynol. 76(1) 49-82.

Prasad M 1994 Siwalik (Middle Miocene) leaf impressions from the foot-hills of Himalayas, India; Tert. Res. 15(2) 53-90.

Prasad M, Ghosh R and Tripathi P P 2004 Floristics and climate during Siwalik (Middle Miocene) near Kathgodam in the Himalayan foot-hills of Uttaranchal, India; J. Palaeontol. Soc. India 49 35-93.

Ramesh Rao 1958 Sterculiaceae; In: Indian woods, their identification, properties and uses, Vol. I (eds) Chowdhury K A and Ghosh S S (Delhi: Manager of Publications), pp. 194-223.

Rao A S 1974 The vegetation and phytogeography of Assam-Burma; In: Ecology and biogeography in India (ed) Mani M S (The Hague, Netherlands: Dr. W Junk b.v. Publishers), pp. 204-246.

Rao M R 2003 Kalviwadithyrites, a new fungal fruiting body from Sindhudurg Formation (Miocene) of Maharashtra, India; Palaeobotanist 52(1-3) 117-119.

Rao M R 2004 Palynological investigation of the Sindhudurg Formation (Miocene) exposed at Kalviwadi, Sindhudurg District, Maharashtra, India; Palaeobotanist 53(1-3) 123-135. 
Roy S K and Mukhopadhyay S 2005 Fossil wood resembling Pterospermum Schreb. (Sterculiaceae) and Tectona Linn. (Verbenaceae) from the Tertiary of West Bengal, India; In: Gleanings in botanical research - current scenario, Ramanujam Commemoration Volume (ed.) Bir Bahadur (Nagpur, India: Dattsons), pp. 221-231.

Saxena R K 1991 A catalogue of fossil plants from India - Part 5A. Tertiary spores and pollen, Birbal Sahni Institute of Palaeobotany, Lucknow, pp. 1-147.

Saxena R K 1995 Sindhudurg Formation - a new lithostratigraphic unit in Konkan area of Maharashtra; Geophytology 24(2) 229-232.

Saxena R K 2000 Palynological investigation of the Sindhudurg Formation in the type area, Sindhudurg District, Maharashtra, India; ONGC Bull. 37(1) 157-166.

Saxena R K and Misra N K 1990 Palynological investigation of the Ratnagiri Beds of Sindhu Durg District, Maharashtra; Palaeobotanist 38 263-276.

Saxena R K, Misra N K and Khare S 1992 Ratnagiri Beds of Maharashtra - lithostratigraphy, flora, palaeoclimate and environment of deposition; Indian J. Earth Sci. 19(4) 205-213.

Saxena R K and Trivedi G K 2006 A catalogue of Indian Tertiary spores and pollen - 1989-2004, Birbal Sahni Institute of Palaeobotany, Lucknow, pp. 1-221.

Serra C 1981 Les structures ligneuses Néogènes du Plateau de Linch (Sud Vietnam); Palaeontographica B 117(5-6) 136-161.

Shallom L J 1963 A fossil dicotyledonous wood with tile cells from the Deccan Intertrappean Beds of Mahurzari; J. Indian Bot. Soc. 42(2) 170-176.

Sheikh M T and Kolhe P D 1980 Fossil wood resembling Sterculia from the Deccan Intertrappean Beds of Mahurzari; Botanique 9(1-4) 77-82.

Shinde N W and Kulkarni A R 1989 Fruits of Nyssa and Eugeissona from lignite exposures of Ratnagiri District; In: Proc. Spec. Indian Geophytological Conference, Poona, 1986 (ed.) Biradar N V (Lucknow: Special Publication of Palaeobotanical Society), pp. 165-169.

Smith A G, Smith D C and Funnell M 1994 Atlas of Mesozoic and Cenozoic coastlines (Cambridge: Cambridge University Press), pp. 1-99.

Soltis D E, Soltis P S, Endress P K and Chase M W 2005 Phylogeny and evolution of angiosperms (Washington: Smithsonian Books), 370p.
Srivastava G and Mehrotra R C 2010 Tertiary flora of Northeast India vis-à-vis movement of the Indian Plate; Geol. Soc. India Memoir 75 123-130.

Srivastava R 1991 A catalogue of fossil plants from India-4. Cenozoic (Tertiary) Megafossils; Birbal Sahni Institute of Palaeobotany, Lucknow, pp. 1-45.

Srivastava R and Awasthi N 1994 Carbonised woods of Sterculiaceae and Sapindaceae from Middle Miocene sediments of Kerala Coast; Palaeobotanist 42(2) 178-182.

Srivastava R and Guleria J S 2000 Grewinium, a substitute name for Grewioxylon Shallom non Schuster; Palaeobotanist 49 531-532.

Srivastava R and Guleria J S 2006 A catalogue of Cenozoic (Tertiary) plant megafossils from India (1989-2005); Birbal Sahni Institute of Palaeobotany, Lucknow Diamond Jubilee Spec. Publ., pp. 1-76.

Srivastava R and Saxena R K 1999 Carbonised woods from the Sindhudurg Formation (Miocene) in Ratnagiri and Sindhudurg districts, Maharashtra, India; Geophytology 27(1-2) 23-33.

Tewari R and Agarwal A 2001 Distinctive stomatal structure from dispersed leaf cuticle of Sindhudurg Formation, Ratnagiri District, Maharashtra, India; Curr. Sci. 81(12) 1638-1641.

Tewari R, Kumar M, Anand-Prakash, Shukla M and Srivastava G P 2002 Dispersed angiosperm cuticles from a lignitic clay bed, Sindhudurg Formation (Miocene), Maharashtra: An interpretation on taxonomy, biodegradation and environment of deposition; Palaeobotanist 50 369-380.

Trivedi B S and Ambwani K 1971 Occurrence of Hibiscoxylon intertrappeum sp. nov. from the Deccan Intertrappean Series of Mahurzari near Nagpur, India; Curr. Sci. 40(7) 167-168.

Wilkie P 2007 A new species of Pterospermum (Dombeyoideae, Malvaceae/Sterculiaceae) from Cambodia and Vietnam; Edinburgh J. Bot. 64(2) 179-183.

Wilkinson G H 1871 Sketch of geological structure of the western Konkan; Rec. Geol. Surv. India 4 44-47.

Worberg A, Alford M H, Quandt D and Borsch T 2009 Huerteales sister to Brassicales plus Malvales, and newly circumscribed to include Dipentodon, Gerrardina, Huertea, Perrottetia, and Tapiscia; Taxon $\mathbf{5 8}$ $468-478$. 